\title{
Path Co-Efficient Analysis for Yield and Yield Attributing Traits in Brinjal [Solanum melongena L.]
}

\author{
Mohanty Kalyan Kumar* and H. N. Mishra
}

Department of Horticulture, Faculty of Agricultural Sciences (IAS), Siksha 'O' Anusadhan

(Deemed to be University), Bhubaneswar-751029, Odisha, India

*Corresponding author

\section{A B S T R A C T}

K e y w o r d s
$\begin{aligned} & \text { Brinjal, Path } \\ & \text { analysis, Direct } \\ & \text { effect, Indirect } \\ & \text { effect }\end{aligned}$
Article Info
$\begin{aligned} & \text { Accepted: } \\ & \text { 07 March } 2020 \\ & \text { Available Online: } \\ & \text { 10 April 2020 }\end{aligned}$

\section{Introduction}

Brinjal [Solanum melongena L.] commonly known as eggplant is an important vegetable crop, cultivated in an area of 0.73 million hectares with a total production of 12.5 million tons having productivity of 18.9 tons per hectare in India (NHB, 2017).

The demand for brinjal variety than the existing ones is always desired for the attributes like higher yield, more number of fruits, high fruit weight, good size fruits, earliness and resistant to diseases and pests.
For selection of any desire genotype for a given environment pardoning the association of various yield contributing traits into direct and indirect effects to understand the relative importance of each trait that influences the yield becomes essential.

Crop improvement through conventional breeding requires an insight into the magnitude of direct and indirect effects of yield component present in a crop species as it forms the basis of effective selection and hence, the present study on path co-efficient analysis in brinjal was taken up. 


\section{Materials and Methods}

Studies were taken up involving 38 germplasm of brinjal [Solanum melongena $\mathrm{L}$.] at Instructional Farm -II, Faculty of Agricultural Sciences (IAS), Siksha 'O' Anusandhan (deemed to be University) Bhubaneswar, Odisha, India during Rabi of 2018. The soil of the experimental plot comes under sandy loam soil (Sand $73.14 \%$, Slit $15.61 \%$, Clay $11.25 \%$ ). The genotypes were collected from different sources. The observations were recorded on five randomly selected plants per replication for each genotype on 12 quantitative characters. The direct and indirect effects were obtained by the method suggested by Dewey and Lu (1959).

\section{Results and Discussion}

In order to find out the cause and effect relationship on yield per plant, path coefficient analysis was carried out taking 12 quantitative traits in brinjal. The correlation of fruit yield per plant with other characters were partitionised into component of direct and indirect effects that would reflect on the nature of these association and relative importance of the components in determining fruit yield. The phenotypic correlation coefficient was used in path analysis and the results (phenotypic path) are presented in Table 1. Phenotypic path analysis (Table 1), revealed that revealed that days to first flowering had the highest positive direct effect (1.512) on fruit yield per plant followed by plant height $(0.515)$, number of fruits per plant (0.461) and fruit weight (0.300), whereas the magnitude was low for node at which first flowering appeared (0.103). Remaining traits showed negative direct effect having highest value in days to $50 \%$ flowering $(-1.320)$ followed by fruit girth ($0.266)$, days to first fruiting $(-0.160)$ and number of branches per plant ( -0.103$)$, days to edible maturity $(-0.081)$ and fruit length (0.076 ) in ascending order.Days to first flowering indicated highest direct effect (1.512) on fruit yield per plant. The indirect, highest effect was mainly resulted by positive indirect effect via. fruit weight (0.093), node at which first flower appeared (0.029), fruit length (0.015) and plant height (0.014). The indirect effect of days to first flowering via days to $50 \%$ flowering $(-1.291)$, days to first fruiting $(-0.150)$, number of fruits per plant ($0.119)$, days to edible maturity $(-0.073)$, fruit girth $(-0.032)$ and number of branches per plant $(-0.013)$ were in negative direction.Days to $50 \%$ flowering showed highest negative direct effect $(-1.320)$ to the fruit yield. The indirect effect of days to 50\% flowering via days to first fruiting $(-0.148)$, number of fruits per plant $(-0.133)$, days to edible maturity $(-0.073)$, fruit girth $(-0.037)$ and number of branches per plant $(-0.015)$ were in negative direction, while rest of the characters such as days to first flowering (1.478), fruit weight (0.097), node at which first flowering appeared (0.029), plant height (0.023), fruit length $(0.020)$ showed positive indirect effect. Plant height showed high direct effect $(0.515)$ to the fruit yield per plant which was mainly contributed by indirect positive effects via. fruit weight (0.104), number of branches per plant (0.051), days to first flowering (0.042), node at which first flowering appeared (0.005) and fruit length (0.003). The indirect effect of plant height was in negative direction via fruit girth ($0.125)$, number of fruits per plant $\quad(-0.073)$, days to $50 \%$ flowing $(-0.059)$, days to first fruiting $(-0.009)$ and days to edible maturity $(-0.008)$. Number of fruit per plant showed positive direct effect (0.461) following plant height to the fruit yield per plant. This effect was exhibited by certain positive indirect effects via days to $50 \%$ flowering (0.380), fruit girth (0.111), days to first fruiting (0.053), days to edible maturity (0.023), number of branches per plant (0.008) and 
node at first flowering appeared (0.003). Rest of the characters showed indirect negative effect being highest on days to first flowering $(-0.392)$ followed by fruit weight $(-0.201)$, plant height $(-0.082)$ and fruit length (0.020). The high positive direct effect $(0.300)$ of fruit weight on fruit yield per plant was observed. It was resulted due to positive indirect effect via. days to first flowing (0.469), plant height (0.179), days to edible maturity (0.023), node at which first flower appeared (0.016), number of branches per plant (0.007) and fruit length (0.001). On the contrary indirect negative effects of fruit weight on yield per plant was exhibited via days to $50 \%$ flowering $(-0.426)$, number of fruits per plant $(-0.310)$, fruit girth $(-0.192)$ and days to first fruiting $(-0.046)$. Node at which first flowering appeared showed positive direct effect $(0.103)$ to the fruit yield per plant in lower magnitude.

It exhibited indirect positive effect via days to first flowering (0.422), node at which first flowering appeared (0.103), fruit weight (0.046), plant height (0.026), number of fruits per plant (0.014) and fruit length (0.005), whereas negative indirect effect was observed by days to $50 \%$ flowering $(-0.375)$, days to first fruiting $(-0.034)$, fruit girth $(-0.027)$, number of branches per plant $(-0.025)$ and days to edible maturity $(-0.017)$. Fruit girth showed negative direct effect $(-0.266)$ on the yield per plant. However, this trait is having indirect positive effect via plant height (0.242), fruit weight (0.216), days to first flowering (0.184), node at which first flowering appeared and fruit length (0.011) and number of branches per plant (0.018) and fruit length (0.011), whereas negative indirect effects were via characters like number of fruits per plant $(-0.192)$, days to $50 \%$ flowing $(-0.185)$, days to first fruit $(-0.024)$ and days to edible maturity $(-0.013)$. Other factors like days to first fruiting $(-0.160)$, number of branches per plant $(-0.130)$, days to edible maturity $(-0.081)$ and fruit length $(-0.076)$ showed negative direct effect to the yield in lower magnitude. Days to first fruiting indicate positive indirect effect via. days to first flowering (1.415), node at which first flowering appeared (0.022), plant height (0.029), fruit length (0.025) and fruit weight (0.085) and negative indirect effect via days to $50 \%$ flowing $(-1.217)$, number of fruit per plant $(-0.154)$, days to edible maturity ($0.077)$, fruit girth $(-0.039)$ and number of branches per plant $(-0.014)$. Further it was observed that fruit length $(-0.076)$ had direct negative effect of lower magnitude to yield per plant, which was mainly resulted due to indirect negative effect governed by characters like days to first flowering ($0.308)$, plant height $(-0.023)$, node at which first flowing appeared $(-0.007)$, fruit weight $(-0.004)$ and number of branches per plant ($0.001)$.

However, this trait exhibited positive indirect effect via. days to $50 \%$ flowering (0.364), number of fruits per plant (0.121), days to first fruiting (0.054), fruit girth (0.038) and days to edible maturity (0.025).From the path analysis, it can be interpreted that days to first flowering, plant height, number of fruits per plant and fruit weight showed high direct effect on fruit yield per plant in brinjal. High indirect effect through these characters was also observed. The above findings clearly indicated that days to first flowering, plant height are two important yield contributing characters in brinjal. Further the correlation coefficient between plant height (0.446), number of fruits per plant (0.344) (both casual factor) and fruit yield per plant (The effect) being positive and having direct effect 0.515 and 0.461 respectively explain the existence of real relationship of that character on fruit yield. Therefore, selection through plant height and number of fruits per plant in brinjal improvement program could be result oriented. 
Table.1 Estimate of direct (diagonal) and indirect effect of component characters on yield in brinjal germplasm

\begin{tabular}{|c|c|c|c|c|c|c|c|c|c|c|c|c|}
\hline Characters & DFFL & NFF & $\begin{array}{l}\text { PH } \\
(\mathbf{c m})\end{array}$ & NB & DF & DFFR & DEM & NF & $\begin{array}{l}\text { FL } \\
\text { (cm) }\end{array}$ & $\begin{array}{l}\text { FG } \\
(\mathbf{c m})\end{array}$ & $\begin{array}{l}\text { FW } \\
\text { (g) }\end{array}$ & $\begin{array}{l}\text { Phenotypic } \\
\text { Correlation } \\
\text { with yield }\end{array}$ \\
\hline DFFL & 1.512 & 0.029 & 0.014 & -0.013 & -1.291 & -0.150 & -0.073 & -0.119 & 0.015 & -0.032 & 0.093 & -0.016 \\
\hline NFF & 0.422 & 0.103 & 0.026 & -0.025 & -0.375 & -0.034 & -0.017 & 0.014 & 0.005 & -0.027 & 0.046 & 0.138 \\
\hline NB & 0.197 & 0.025 & -0.256 & -0.103 & -0.193 & -0.022 & -0.010 & -0.036 & -0.001 & 0.047 & -0.022 & -0.374 \\
\hline DF & 1.478 & 0.029 & 0.023 & -0.015 & -1.320 & -0.148 & -0.073 & -0.133 & 0.020 & -0.037 & 0.097 & -0.078 \\
\hline DFFR & 1.415 & 0.022 & 0.029 & -0.014 & -1.217 & -0.160 & -0.077 & -0.154 & 0.025 & -0.039 & 0.085 & -0.085 \\
\hline FL $(\mathbf{c m})$ & -0.308 & -0.007 & -0.023 & -0.001 & 0.364 & 0.054 & 0.025 & 0.121 & -0.076 & 0.038 & -0.004 & 0.183 \\
\hline FG(cm) & 0.184 & 0.011 & 0.242 & 0.018 & -0.185 & -0.024 & -0.013 & -0.192 & 0.011 & -0.266 & 0.216 & 0.002 \\
\hline FW(g) & 0.469 & 0.016 & 0.179 & 0.007 & -0.426 & -0.046 & 0.023 & -0.310 & 0.001 & -0.192 & 0.300 & -0.025 \\
\hline
\end{tabular}

Residual effect $=0.695$

Figures in bolded denoted the Direct Effect $\mathrm{DFFL}=$ Days to first flowering $\mathrm{NB}=$ Number of branches per plant $\mathrm{DEM}=$ Days to edible maturity $\mathrm{FG}=$ Fruit girth $(\mathrm{cm})$
$\mathrm{NFF}=$ Node at which first flowering appeared $\mathrm{DF}=$ Days to $50 \%$ flowering

$\mathrm{NF}=$ Number of fruits per plant

$\mathrm{FW}=$ Fruit weight $(\mathrm{g})$
$\mathrm{PH}=$ Plant height $(\mathrm{cm})$

$\mathrm{DFFR}=$ Days to first fruiting

$\mathrm{FL}=$ Fruit length $(\mathrm{cm})$ 
The phenotypic path coefficient analysis revealed that days to first flowering, plant height, and number of fruits per plant and fruit weight have maximum direct effect on fruit yield of brinjal. Further, node at which first flowering appeared have also produce positive direct effect of lower magnitude on yield of brinjal. On the other hand, days to 50 percent flowering followed by fruit girth have the maximum negative direct effect on fruit yield of brinjal.

Other characters such as number of branches per plant, days to first fruiting, days to edible maturity and fruit length have also exhibited negative direct effect of lower magnitude on fruit yield of brinjal. The low positive or negative direct effect resulted due to cancelation by the respective indirect effect via. days to first flowering, plant height, number of fruits per plant, fruit weight and node at which first flowering appeared. The indirect effect of days to first flowering via. fruit weight, fruit length, plant height and node at which first appeared thus producing high positive direct effect for these characters.

Similarly plant height, node at which first flowering appeared and fruit weight have the highest direct effect which are mainly contributed by fruit weight, number of branches per plant and days to first flowering, days to 50 percent flowering and fruit girth, days to first flowering, plant height and days to edible maturity.

The present findings are in agreement with Dharwad et al., (2009), Senapati et al., (2009), Dahatonde et al., (2010), Kumar et al., (2011), Arunkumar et al., (2013), Lakshmi et al., (2014), Yadav et al., (2014), Samlindsujin et al., (2017), Singh and Singh (2016), Jhangta et al., (2017) and Chauhan et al., (2017) on fruit yield of brinjal. On the basis of foregoing discussion, it may be inferred that days to first flowering, plant height, number of fruits per plant and node at which first flowering appeared have considerable direct contribution to fruit yield in brinjal, High indirect effects through these traits were also observed.

This clearly indicates that direct selection for these characters would be beneficial for improvement in fruit yield of brinjal since all those characters also show positive correlation with fruit yield. Other characters which had shown significant correlation with fruit yield per plant are mainly due to indirect effect via. these character.

\section{References}

Arunkumar B, Kumar SVS and Chandra PJ 2013. Genetic Variability and Divergence Studies in Brinjal (Solanum melongena L.), Bioinfolet 10(2).

Chauhan A, Chandel KS and Singh SP 2017. Studies on Correlation and Path Analysis for Yield and Yield Contributing Traits in Eggplant (Solanum melongena L) Involving Bacterial Wilt Resistant Genotypes, Vegetos 30(4): 118-121.

Dahatonde K, Dod VN, Nagre PK and Wag AP 2010. Correlation and Path Analysis Studies in Purple Fruited Brinjal, Asian Journal of Horticulture 5 (2): 428-430.

Dewey DR and Lu KH 1959. A correlation and path co-efficient analysis of components of crested wheat grass seed production, Agronomy Journal 51:512515.

Dharwad NA, Salimath PM and Patil SA 2009. Association and Path co-efficient Analysis in Elite Germplasm Lines of Brinjal (Solanum melongena L.), Journal of Farm Sciences 22 (5).

Jhangta M, Chandel KS and Chauhan A 2017. Correlation and Path Analysis Studies in Brinjal (Solanum melongena L.), Vegetable Science 44 (1): 93-97.

Kumar A, Kumar S and Yadav YC 2011. 
Correlation and Characters Association Studies in Brinjal (Solanum melongena L.), Asian Journal of Horticulture 6(1):221

Lakshmi RR, Padma SSV, Naidu LN and Umajyothi K 2014. Correlation and Path Analysis Studies of Yield and Yield Components in Brinjal, Plant Archives 14(1): 583-591.

Samlindsujin G and Karuppaiah P 2016. Studies on Genetic Divergence in Brinjal (Solanum melongena L.) for Yield Attributes and Shoot and Fruit Borer (Leucinodes arbonalis) Incidence, International Journal of Plant Sciences 11(1): 47-50.
Senapati N, Mishra HN, Bhoi MK, Dash SK and Prasad G 2009. Genetic Variability and Divergence Studies in Brinjal (Solanum melongena L.), Vegetable Science 36 (2): 150-154.

Singh PP and Singh D 2016. Genetic Variability Studies for Improvement in Brinjal under Hot Arid Agro-Climate, Indian Journal of Horticulture 73(3):449-452.

Yadav V, Mehta N, Rangare SB and Sahu E 2014. Causal Influence of Background Traits on Fruit Yield in Egg Plant (Solanum melongena L.), Trends in Biosciences, 7(24):4149-4152.

\section{How to cite this article:}

Mohanty Kalyan Kumar and Mishra. H. N. 2020. Path Co-Efficient Analysis for Yield and Yield Attributing Traitsin Brinjal [Solanum Melongena L.]. Int.J.Curr.Microbiol.App.Sci. 9(04): 767-772. doi: https://doi.org/10.20546/ijcmas.2020.904.091 